\title{
KAJIAN ENERGI GELOMBANG LAUT DI DAERAH ABRASI SERANGAI, BENGKULU UTARA MELALUI PENGAMATAN TINGGI GELOMBANG LAUT
}

\author{
Ashar Muda Lubis ${ }^{1}$, Yosi Apriani Putri ${ }^{1}$, Rio Saputra ${ }^{1}$, Juhendi Sinaga ${ }^{1}$, \\ M. Hasanudin ${ }^{2}$ dan Edi Kusmanto ${ }^{2}$ \\ ${ }^{1}$ Jurusan Fisika, Fakultas Matematika dan Ilmu Pengetahuan Alam, Universitas Bengkulu, \\ Jl. WR. Supratman, Kadang Limun, Muara Bangkahulu, Bengkulu, 38371 \\ ${ }^{2}$ Pusat Penelitian Oseanografi, Lembaga Ilmu Pengetahuan Indonesia \\ Jl. Pasir Putih I, Ancol Timur, Jakarta 14430, Indonesia \\ *) Email korespondensi: asharml@unib.ac.id
}

Received 29-03-2021, Revised 17-07-2021, Accepted 15-08-2021, Published 01-10-2021

\section{ABSTRACT}

The Serangai area, Batik Nau District, North Bengkulu has the highest average abrasion speed of $20 \mathrm{~m} /$ year. The abrasion could cause the coastal area to erode the coastline till several tens of meters. The purpose of this study was to determine the height of the ocean waves and to determine the energy of the ocean waves that has the potential to accelerate the abrasion process in the Serangai area. The research was carried out on November 5-7, 2018 in the Serangai beach area at a depth of $5 \mathrm{~m}$ using SBE 26 Plus Seagauge Wave equipment. The results showed that the observed wave height was between 0.8-1.6 m with a significant wave height (Hs) of $1.38 \mathrm{~m}$. In addition, the wave period ranges from 5-11 s with a significant wave period (Ts) of $8.2 \mathrm{~s}$. The result also shows that the maximum wave height of $1.6 \mathrm{~m}$ occurred on November 7, 2018 with maximum wave energy of $1800 \mathrm{~J} / \mathrm{m}^{2}$. This result can perhaps accelerate the abrasion process in the Serangai area. It can also be seen that the wave height in the Serangai region is higher than in several other areas in Indonesia. However, it is necessary to continue observing the wave height to see the seasonal variations in sea wave height in Serangai area.

Keywords: Serangai, abrasion, height, wave and energy.

\section{ABSTRAK}

Daerah Serangai, Kecamatan Batik Nau, Bengkulu Utara memiliki kecepatan abrasi rata-rata tertinggi, mencapai 20 meter per tahun . Abrasi yang terjadi menyebabkan kawasan pantai tergerus beberapa puluh meter lebih dari garis pantai. Tujuan dari penelitian ini adalah untuk mengetahui ketinggian gelombang laut dan mengetahui energi gelombang laut yang berpotensi mempercepat proses abrasi di daerah Serangai. Penelitian telah dilaksanakan pada tanggal 5-7 November 2018 di kawasan pantai Serangai pada kedalaman 5 m dengan menggunakan peralatan SBE 26 Plus Seagauge Wave. Hasil penelitan menunjukkan bahwa tinggi gelombang teramati antara 0,8-1,6 m dengan tinggi gelombang singnificant $(\mathrm{Hs})$ 1,38 m. Kemudian periode gelombang berkisar antara 5-11 detik dengan periode gelombang significant (Ts) sebesar 8,2 detik. Hasil penelitian menunjukkan bahwa tinggi gelombang maksimum terjadi pada tanggal 7 November 2018 berkisar 1,6 m dengan energi gelombang sekitar $1800 \mathrm{~J} / \mathrm{m}^{2}$. Tingginya gelombang laut di daerah Serangai dapat mempercepat proses abrasi. Berdasarkan hasil-hasil penelitian ini juga, dapat dilihat bahwa tinggi gelombang di daearah Serangai lebih tinggi jika dibanding di beberapa daearah lain di Indonesia. Namun demikian diperlukan pengamatan tinggi gelombang lanjutan untuk melihat variasi musiman tinggi gelombang laut di Serangai. 


\section{PENDAHULUAN}

Provinsi Bengkulu merupakan salah satu provinsi yang sebagian wilayahnya berada di pesisir dan laut dengan panjang garis pantai mencapai $\pm 586 \mathrm{~km}$ yang memanjang dari perbatasan Provinsi Sumatra Barat sampai perbatasan Provinsi Lampung. Provinsi Bengkulu memiliki karakteristik pantai yang bervariasi antara landau dan curam dimana beberapa dekade terakhir wilayah pantai Bengkulu mengalami kerusakan karena adanya proses abrasi pantai. Abrasi adalah proses pengikisan pantai oleh tenaga gelombang laut dan arus laut yang bersifat merusak tersebut berupa perubahan garis pantai.

Peristiwa abrasi terjadi di beberapa desa di Bengkulu Utara sehingga kawasan tersebut mengalami kemuduran beberapa puluh meter dari bibir pantai ${ }^{[1]}$. Peristiwa abrasi pantai merupakan salah satu penyebab utama terjadinya perubahan garis pantai di Provinsi Bengkulu bagian utara. Berdasarkan hasil penelitian Lubis $\mathrm{dkk}^{[1]}$ daearah Serangai, Kecematan Batik Nau, Kabupaten Bengkulu Utara merupakan daerah yang terparah mengalami kerusakan pantai dengan kecepatan abrasi maksimum mencapai 29 m/tahun. Proses abrasi terjadi dikarenakan adanya faktor lokal atau penyebab abrasi seperti perbedaan struktur batuan penyusun pantai yang lunak, besar kecilnya hempasan energi gelombang laut pada lokasi tersebut dan adanya arus sejajar pantai (longshore current) yang dapat mengerus pantai dan membawa material-material gerusan ke tempat lain.

Disamping itu faktor yang berperan dalam perubahan garis pantai adalah faktor sedimentasi pada muara sungai di daerah pantai dan faktor tektonik yang berhubungan dengan deformasi tektonik daerah pantai akibat gempa bumi maupun tsunami dan perubahan permukaan air laut karena pengaruh perubahan iklim (pemanasan global). Deformasi vertikal akibat proses tektonik pada daerah pantai juga akan rentan terhadap perubahan garis pantai maupun erosi atau abrasi daerah pantai. Bila kawasan pantai mengalami kenaikan maka dinding pantai akan semakin mudah dikikis oleh gelombang laut sehingga memudahkan terjadinya terjadi peristiwa abrasi dan erosi karena hantaman gelombang laut dengan ketinggian tertentu. Apabila daerah pantai mengalami penurunan, maka daerah ini akan berubah menjadi lautan dan juga terjadi perubahan garis pantai yang jelas.

Disisi lain, penelitian tentang pengaruh perubahan iklim pada fenomena abrasi pantai di Bengkulu melalui pengamatan perubahan muka air laut dengan satelit Altimetry telah dilakukan $^{[2]}$. Hasil pengolahan data selama periode tahun 1994-2013 menunjukkan bahwa ada perubahan muka air laut secara tahunan di wilayah perairan Bengkulu namun tidak tampak secara signifikan ${ }^{[2]}$. Laju perubahan muka air laut yang didapatkan pada perairan daerah Bengkulu ini masih relatif lebih kecil jika dibandingkan terhadap laju perubahan muka air laut secara global, yakni $1,7 \mathrm{~mm} / \operatorname{tahun}^{[3,4,5]}$. Kemudian laju perubahan muka air laut di daerah Bengkulu tidak terlihat berkolerasi linear terhadap laju abrasi di pantai Bengkulu Utara, sehingga karena kecilnya perubahan muka air laut di daerah ini, maka dapat disimpulkan bahwa faktor perubahan muka air laut bukan merupakan penyebab utama abrasi pantai di Bengkulu bagian utara. Dengan demikian diperlukan penelitian lanjutan tentang kemungkinan faktor lain yang menjadi penyebab abrasi pantai seperti faktor tektonik.

Kemudian faktor lain yang dapat mempercepat proses abrasi pantai adalah faktor besar kecilnya hempasan energi gelombang laut pada suatu tempat. Energi gelombang laut yang berhubungan dengan ketinggian gelombang laut pada daerah pantai akan memberikan energi hempas oleh gelombang laut yang tergantung pada besar kecilnya dan tinggi rendah tinggi gelombang laut yang menghepas pantai. 
Gelombang laut yang memiliki ketinggian puncak maksimum dan lembah minimum. Pada selang waktu tertentu, ketinggian puncak yang dicapai serangkaian gelombang laut berbedabeda, bahkan ketinggian untuk lokasi yang sama. Karena daerah pantai Serangai memiliki rata-rata kecepatan abrasi tertinggi, maka diperlukan penelitian berapa besarnya energi gelombang laut di daeah pantai Serangai dengan menentukan tinggi gelombang laut pada daerah tersebut.

Tujuan penelitian ini adalah untuk mengetahui energi gelombang laut melalui pengamatan tinggi gelombang laut di daerah pantai Serangai, Kecamatan Batik Nau, Bengkulu Utara dengan menggunakan alat SBE 26 Plus Seagauge Wave. Penelitian ini dapat dimanfaatkan dalam kajian penentuan penyebab abrasi panati di daeah Bengkulu Utara khususnya di daerah Serangai. Di sisi lain juga dapat dijadikan sebagai bahan referensi dalam perancangan pembangkit listrik tenaga gelombang gelombang laut dalam mengembangan energi alternatif di masa yang akan datang melalui pemanfaatan energi gemobang laut yang juga dapat dijadikan sebagai dasar penentuan perencanaan dan kebijakan daerah khususnya di Provinsi Bengkulu.

\section{METODE}

Penelitian ini diawali dengan survey pendahuluan penelitian untuk mencari lokasi tempat alat penelitian untuk pengambilan data tinggi gelombang laut di daerah Serangai, Kecamatan Batik Nau, Kabupaten Bengkulu Utara. Lokasi penelitian secara jelasnya dapat dilihat pada Gambar 1.

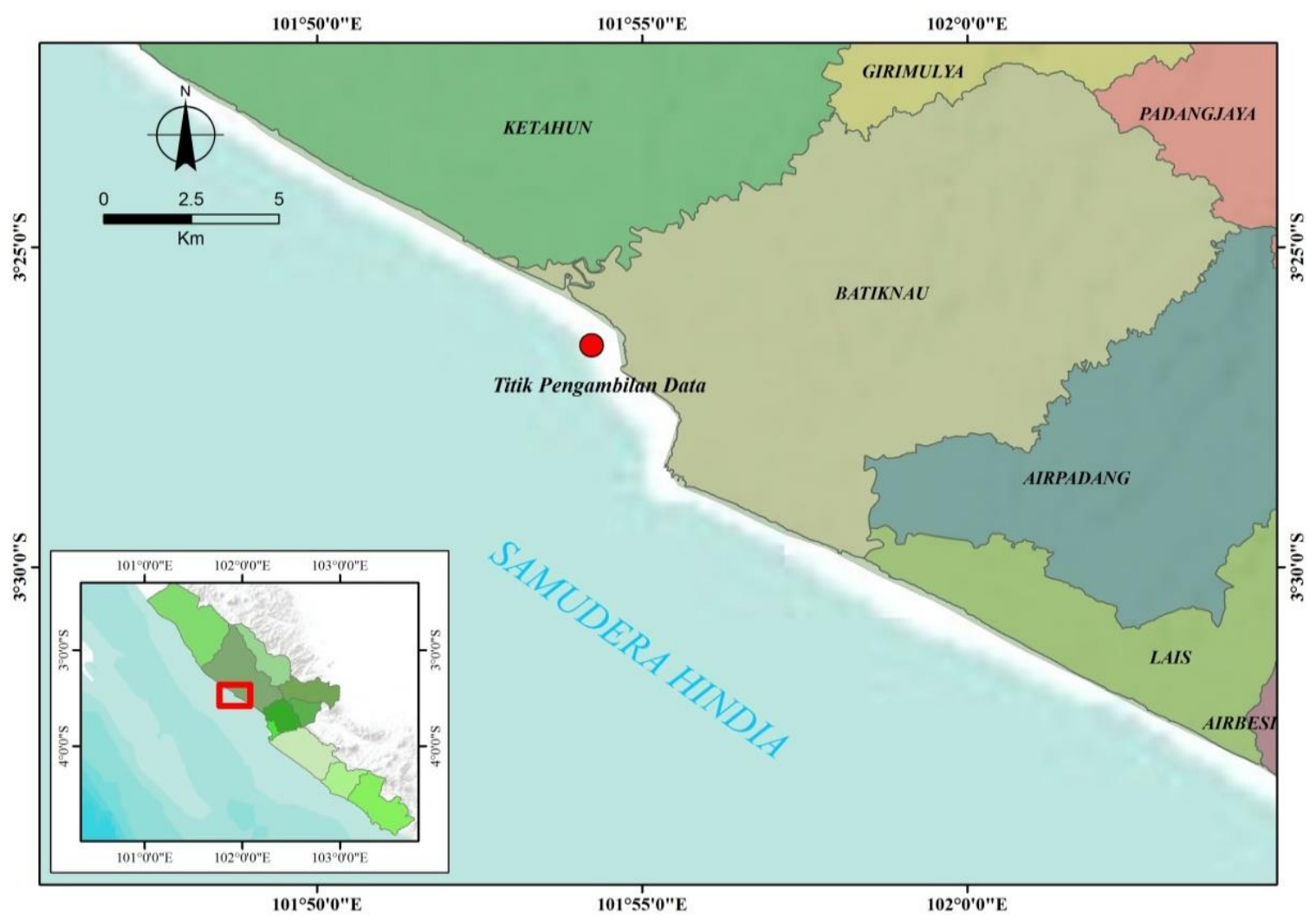

Gambar 1. Lokasi penelitian tempat pengukuran tinggi gelombang laut di daerah Serangai, Kecamatan Batik Nau, Bengkulu Utara (titik merah).

Pengukuran langsung dilakukan untuk memperoleh data tinggi dan periode gelombang laut menggunakan alat SBE 26 Plus Seagauge Wave. Alat tersebut diletakkan pada pada koordinat $3^{\circ} 25^{\prime} 825^{\prime \prime}$ LS dan $101^{\circ} 53^{\prime} 440^{\prime}$ BT dan diletakkan pada dasar perairan pada 
kedalaman $5 \mathrm{~m}$ dimana keadaan pantai yang terbuka sehingga gelombang yang terukur bukan dari gelombang pantul dari sekitarnya. Sensor menghadap ke samping terhadap bibir pantai dengan jarak kira-kira $20 \mathrm{~m}$ dari garis pantai, sehingga peralatan tetap bisa terpantau dari pinggir pantai. Pengukuran parameter gelombang dilakukan selama 48 jam dengan interval waktu pengukuran setiap 10 detik pada tanggal 5-7 November 2018.

Dalam Penelitian ini pengolahan data dilakukan dengan data primer berupa data parameter gelombang hasil pengukuran menggunakan SBE 26 Plus Seagauge Wave. Data yang terkumpul berupa bentuk data format .hex yang kemudian dikonvesi kedalam bentuk .txt file. Data gelombang hasil pengukuran gelombang laut di lapangan dianalisis untuk mendapatkan besarnya energi gelombang laut di daerah Serangai. Semakin tinggi gelombang terbentuk maka nilai energi gelombang akan semakin besar dan begitu sebaliknya $^{[6]}$.

Energi total gelombang (E) adalah jumlah dari energi kinetik $\left(E_{K}\right)$ dan energi potensial $\left(E_{P}\right)$. Energi kinetik merupakan energi yang disebabkan oleh kecepatan partikel air karena adanya pergerakan gelomabang dan energi potensial merupakan energi yang dihasilkan oleh perpindahan muka air karena adanya gelombang. Energi potensial yang timbul akibat adanya elevasi muka air terhadap Static Water Level (SWL) adalah:

$$
E_{P}=\frac{1}{16} \rho g H^{2}
$$

dimana $\rho$ adalah densitas air laut, $g$ adalah percepatan gravitasi bumi dan $H$ adalah ketinggian gelombang laut. Kemudian energi kinetik yang timbul karena adanya gerak partikel air adalah:

$$
E_{K}=\frac{1}{16} \rho g H^{2}
$$

Dengan demikian energi total gelombang (E) adalah jumlah dari energi kinetik dan energi potensial adalah:

$$
\begin{aligned}
& \mathrm{E}=E_{P}+E_{K} \\
& \mathrm{E}=\frac{1}{16} \rho g H^{2}+\frac{1}{16} \rho g H^{2} \\
& \mathrm{E}=\frac{1}{8} \rho g H^{2}
\end{aligned}
$$

Energi diatas menyatakan energi gelombang persatuan luas atau disebut kecepatan energi, sedangkan untuk untuk energi persatuan lebar (L) dinyatakan dalam bentuk:

$$
\begin{aligned}
& \mathrm{E}=E_{P}+E_{K} \\
& \mathrm{E}=\frac{1}{16} \rho g H^{2} L+\frac{1}{16} \rho g H^{2} L \\
& \mathrm{E}=\frac{1}{8} \rho g H^{2} L
\end{aligned}
$$

Berdasarkan persamaan (4) semakin besar tinggi gelombang $\mathrm{H}$ maka daya gelombang yang dihasilkan juga semakain besar. Kemudian daya gelombang (P) yang merupakan laju dimana energi dirambatkan persatuan panjang dari puncak gelombang dapat dihitung dengan menggunakan persamaan daya gelombang sebagai berikut:

$$
\mathrm{P}=0,55 \times H^{2} T T_{Z}
$$

dimana $\mathrm{T}$ adalah perioda gelombang dan $T_{Z}$ merupakan zero crosing period ${ }^{[7]}$. 


\section{HASIL DAN PEMBAHASAN}

Pengambilan data tinggi gelombang dan periode gelombang laut telah dilakukan di daerah penelitian yang terletak di daerah Serangai Kecamtan Batik Nau, Bengkulu Utara. Penelitian dilakukan pada tanggal 5-7 November 2018 dengan menggunakan perangkat SBE 26 Plus Seagauge Wave. Hasil pengukuran tinggi gelombang laut di daerah pantai Serangai diperlihatkan pada Gambar 2. Pada tanggal 5 November 2018, tinggi gelombang laut tertinggi berkisar 1,2-1,5 m pada pukul 20:15 WIB dan 16:14 WIB, sedangkan tinggi gelombang terendah berkisar 0,8 m pada pukul 11:16 WIB (Gambar 2). Dari pengukuran gelombang laut ini di daerah Serangai diperoleh hasil energi gelombang laut tertinggi berkisar $1800 \mathrm{~J} / \mathrm{m}^{2}$ pada pukul 16:14 WIB dengan energi gelombang terendah berkisar 600 $\mathrm{J} / \mathrm{m}^{2}$ pada pukul 11:16 WIB.

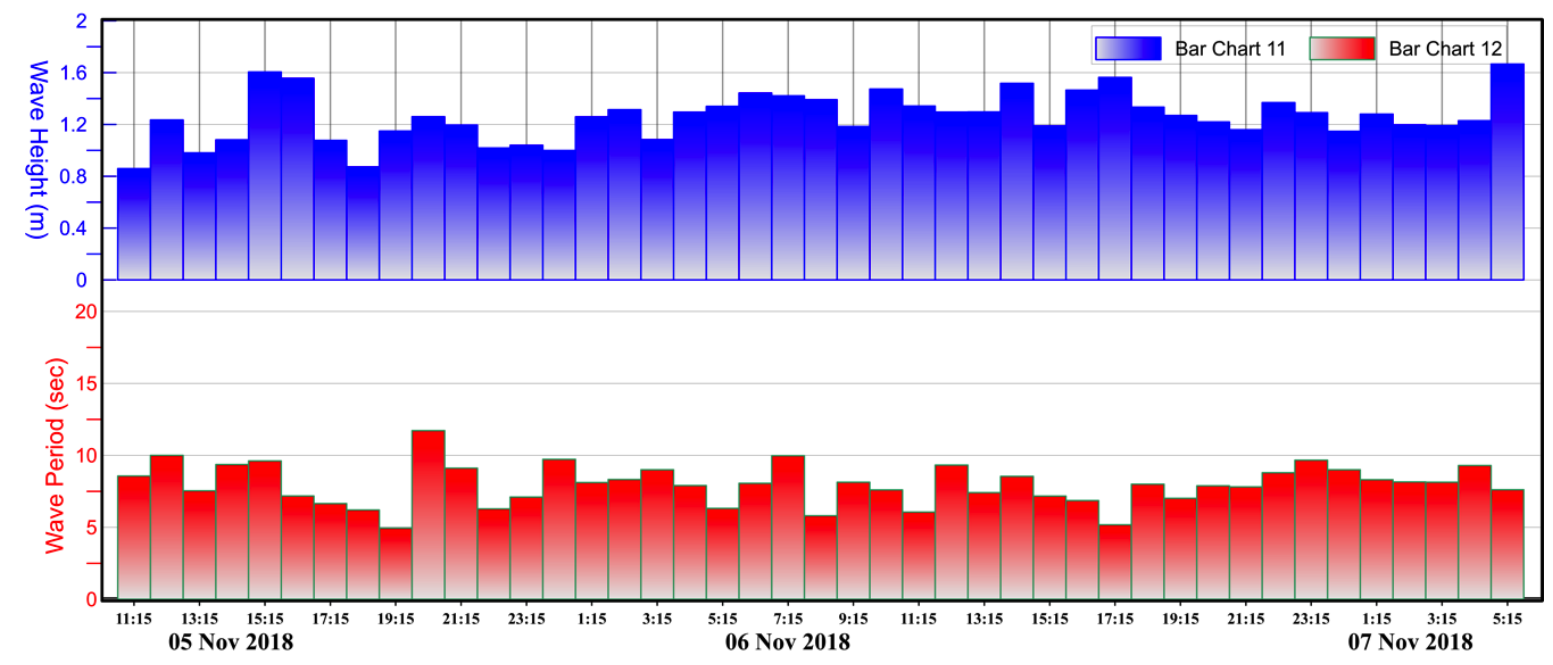

Gambar 2. Grafik tinggi gelombang laut (histogram merah) terhadap energi (histogram biru).

Pada tanggal 6 November 2018, tinggi gelombang laut tertinggi berkisar 1,3-1,4 m pada pukul 17:16 WIB dan 6:15 WIB. Kemudian tinggi gelombang terendah berkisar 0,9 m pada pukul 00:14 WIB. Selanjutnya pada tanggal 7 November 2018, tinggi gelombang laut maksimum berkisar 1,2-1,6 m pada pukul 1:15 WIB dan 5:15 WIB dan tinggi gelombang minimum berkisar $1 \mathrm{~m}$ pada pukul 00:14 WIB. Perhitungan energi gelombang laut pada tanggal 6 November 2018 memberikan besarnya energy berkisar antara 1000-1700 J/m². Kemudian pada tanggal 7 November 2018, energi gelombang laut berkisar antara 1000$1800 \mathrm{~J} / \mathrm{m}^{2}$.

Pada Gambar 3 diperlihatkan hasil periode gelombang laut di Perairan Desa Serangai, Bengkulu Utara. Hasil pengukuran data gelombang lapangan di Perairan Serangai pada tanggal 5 November 2018 memperlihatkan bahwa periode gelombang laut tertinggi berkisar 10-12 detik pada pukul 12:15 WIB dan 19:16 WIB dengan periode terendah 5 detik pada pukul 18:16 WIB. Selanjutnya pada tanggal 6 November 2018 periode gelombang laut tertinggi berkisar 8,5-9,6 detik pada pukul 14:15 WIB dan 23:14 WIB dengan periode terendah berkisar 5 detik pada pukul 17:16 WIB. Pada tanggal 7 November 2018 periode tertinggi berkisar 8-9 detik pada pukul 1:16 WIB dan 4:15 WIB dengan periode terendah berkisar 7,6 detik pada pukul 5:15 WIB. 


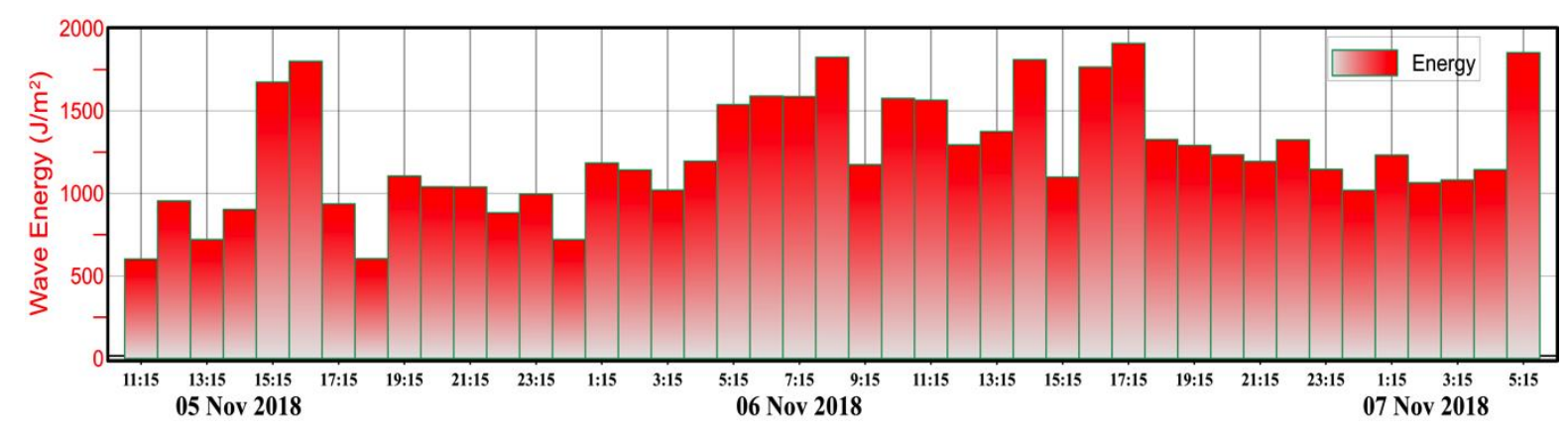

Gambar 3. Grafik Periode Gelombang Laut.

Berdasarkan hasil pengukuran tinggi gelombang laut di daerah Serangai, maka diperoleh tinggi gelombang significant ((Hs) dan periode gelombang significant (Ts), tinggi gelombang maksimum (Hmax) dan periode gelombang maksimal (Tmax) serta tinggi gelombang minimum (Hmin) dan periode minimum (Tmin) diperlihatkan pada Gambar 4. Berdasarkan hasil perhitungan diperoleh bahwa tinggi gelombang significant (Hs) sebesar $1,38 \mathrm{~m}$ dan tinggi gelombang minimum (Hmin) sebesar $0.8 \mathrm{~m}$ pada tanggal 5 November 2018 pada pukul 11:16 WIB. Kemudian tinggi gelombang maksimum (Hmax) sebesar $1 \mathrm{~m}$ pada tanggal 7 November 2018 pukul 05:15 WIB. Hasil penelitian menunjukkan bahwa hasil periode gelombang signifikan (Ts) 8,2 detik, periode gelombang maksimal (Tmax) 11 detik pada tanggal 5 November 2018 pukul 20:15 WIB dan periode minimum (Tmin) 5 detik pada tanggal 6 November 2018 pukul 17:16 WIB. Energi gelombang sebesar $1800 \mathrm{~J} / \mathrm{m}^{2}$.

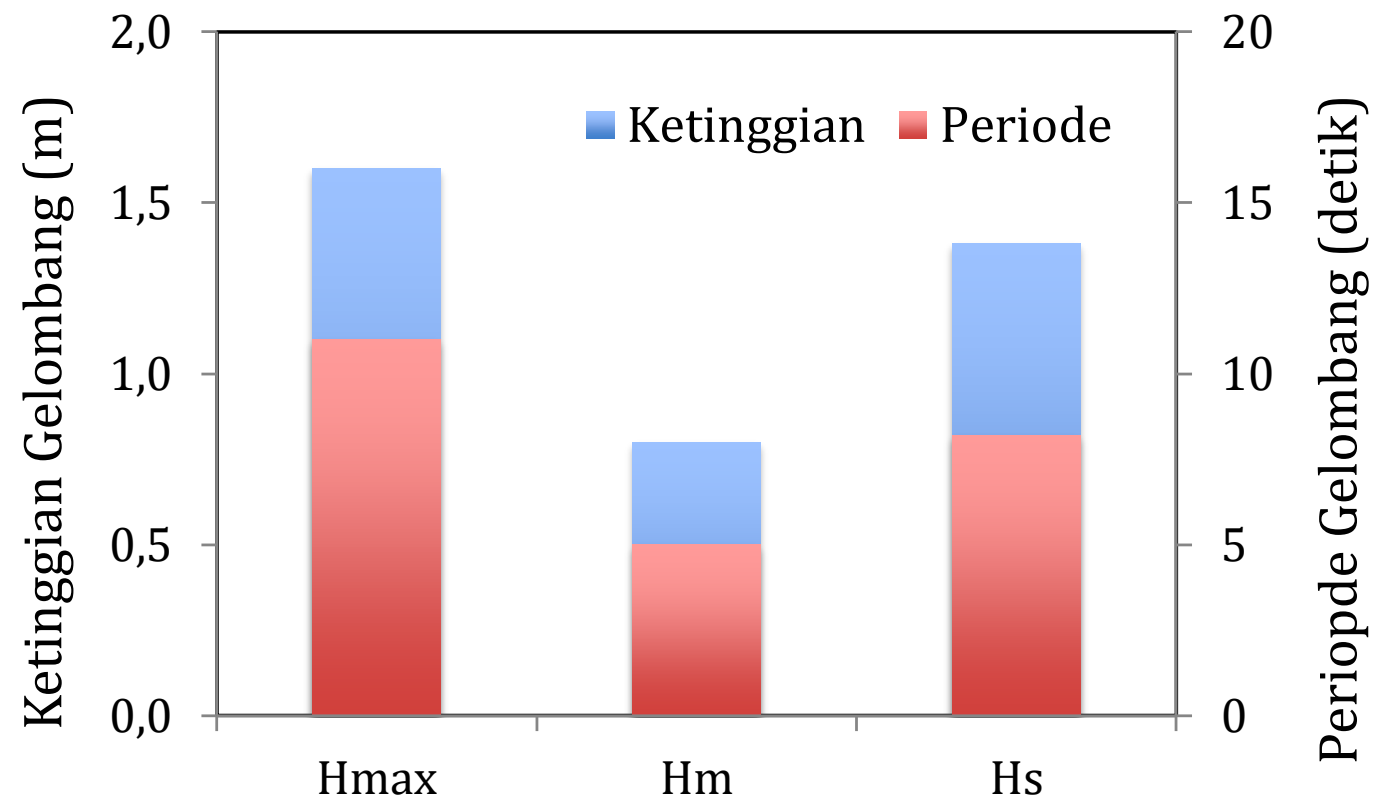

Gambar 4. Tinggi gelombang laut dan periode pengukuran di daerah pantai Serangai.

Dari hasil penelitian juga diperoleh periode gelombang berkisar anatar 5-11 detik dimana gaya pembangkit gelombang yang terbentuk di daerah Serangai merupakan gelombang yang dibangkitkan angin dengan tipe gelombang swell wave (gelombang alun). Menurut Holthuijsen $^{[8]}$ yang mengklasifikasikan tipe gelombang berdasarkan periode gelombang dimana gelombang laut yang mempunyai periode gelombang antara 0.9-15 detik merupakan 
gelombang yang dibangkitkan angin dengan tipe gelombang swell wave. Tipe panjang gelombang seperti ini bisa mencapai ratusan meter.

Dari kajian yang telah dilakukan terlihat bahwa energi gelombang laut di daerah abrasi Serangai, Bengkulu Utara termasuk dalam katagori besar. Hal ini bila dibandingkan dengan beberapa daerah lain di Indonesia (Tabel 1). Berdasarkan hasil penelitian Jejen $\mathrm{dkk}^{[9]}$ yang dilakukan di daerah Karimun Jawa Jawa Tengah pada tanggal 19-22 September mengamati bahwa tinggi gelombang laut relatif lebih kecil antara 0.10-0,38 m. Kemudian penelitian Mizan dkk ${ }^{[10]}$ yang dilakukan di daerah Pulau Panjang Jawa Tengah pada tanggal 7-11 Maret 2019 juga relatif kecil dengan tinggi gelombang laut maksimum 0,44 m. Sementara itu di daerah Pantai Boom Tuban, Jawa Timur pada tanggal 27-29 Juni 2014 bahwa tinggi gelombang laut berkisar $0,25-0,50 \mathrm{~m}^{[11]}$.

Kemudian tinggi gelombang laut maksium pada Perairan Semarang pada tanggal 9-14 Agustus 2010 memperlihatkan masih dibawah $0,90 \mathrm{~m}^{[12]}$. Pada daerah lain, penelitian Utama $^{[13]}$ yang dilakukan di daerah Selat Malaka, Selat Natuna dan Selat Kalimata pada tanggal 28 April-5 Mei 2010 memperlihatkan bahwa tinggi gelombang laut 0,20-1,40 m, sedangkan di daerah Perairan Batu Bara, Sumatra Utara pada pada tanggal 17-20 Juni 2014 relatif tinngi gelombang yang teramati lebih kecil yakni $0,24-0,54 \mathrm{~m}^{[14]}$. Terakhir penelitian Shintawati ${ }^{[15]}$ di perairan Kepulauan Sablana pada bulan Juli 2018 tinggi gelombang laut berkisar 1,00-1,20 m.

Tabel 1. Tinggi Gelombang Laut Beberapa Daerah

\begin{tabular}{|c|c|c|c|c|}
\hline \multirow{2}{*}{ Lokasi } & \multicolumn{3}{|c|}{ Tinggi Gelombang (m) } & \multirow{2}{*}{ Sumber } \\
\hline & Hmaks & Hmin & $\mathrm{Hs}$ & \\
\hline Karimun Jawa, Jawa Tengah & 0.38 & 0,10 & 0,23 & Jejen $\mathrm{dkk}^{[9]}$ \\
\hline Pulau Panjang & 0,44 & 0,01 & 0,11 & Mizan dkk ${ }^{[10]}$ \\
\hline Pantai Boom Tuban, Jawa Timur & 0,50 & 0,25 & 0,33 & Rahma dkk $^{[11]}$ \\
\hline Perairan Semarang & 0,89 & 0,18 & 0,58 & Intan $\mathrm{dkk}^{[12]}$ \\
\hline Selat Kalimata & 1,25 & 0,40 & 0,80 & Utami $^{[13]}$ \\
\hline Selat Malaka & 0,50 & 0,20 & 0,40 & Utami $^{[13]}$ \\
\hline Laut Natuna & 1,40 & 0,60 & 1,25 & Utama $^{[13]}$ \\
\hline Perairan Batu Bara, Sumatra Utara & 0,54 & 0,24 & 0,40 & Ryan dkk ${ }^{[14]}$ \\
\hline Perairan Kepulauan Sablana & 1,20 & 1,00 & 0,75 & Shintawati ${ }^{[15]}$ \\
\hline Serangai, Bengkulu & 1,66 & 0,85 & 1,38 & Penelitian ini \\
\hline
\end{tabular}

Tingginya gelombang laut di daerah perairan Serangai lebih tinggi jika dibandingkan dengan daerah lain (Tabel 1) dengan ketinggian maksimum 1,66 m. Hal ini karena perairan ini lebih terbuka dan berhadapan langsung dengan Samudra Hindia. Besarnya tinggi gelombang yang teramati di daerah ini berhubungan dengan energi gelombang laut yang relatif besar yakni mencapai $1800 \mathrm{~J} / \mathrm{m}^{2}$. Hal ini dapat menjadi salah satu faktor penyebab cepatnya laju abrasi yang tinggi di Desa Serangai Kecamatan Batik Nau, Bengkulu Utara ${ }^{[1]}$. Fenomena ini diperparah bahwa arus sejajar pantai di daerah ini juga sangat tinggi yang mencapai $30 \mathrm{~cm} /$ detik $^{[16]}$. Dengan nilai arus sejajar pantai yang $>10 \mathrm{~cm} /$ detik, maka arus sejajar pantai dapat mempercepat proses abrasi karena keberadaan arus ini dapat mengangkut sedimen berukuran $0,6 \mathrm{~mm}^{[17]}$ akibat hempasan energi gelombang laut pada dinding pantai yang curam. Keberadaan arus sejajar pantai ini sangat dipengaruhi oleh tinggi gelombang di daerah pantai dan sudut gelombang yang terbentuk terhadap arus pantai ${ }^{[18]}$.

Apabila dibandingkan tinggi gelombang laut pada 9 daerah penelitian lainnya (Tabel 1), dapat dilihat bahwa di daerah Serangai memiliki nilai tinggi gelombang significan (Hs) tertinggi yaitu 1,38 m dengan Hmax 1,66 m dan Hmin 0,85 m, meskipun perbandingan ini 
belum melihat secara jelas waktu pengambilan data pada 9 daerah lain tersebut. Tinggi rendahnya gelombang laut di pengaruhi oleh musim (waktu) dan pergerakan angin. Penelitian ini dilakukan pada bulan November 2018, yang mana pada bulan November terjadi angin muson barat dimana pada musim ini tekanan udara di daerah Asia lebih tinggi dibandingkan di daerah Australia, sehingga angin yang bertiup melewati Samudera Hindia sehingga akan banyak membawa uap air dan menggasilkan musim penghujan. Pada musim ini juga gelombang laut mengalami ketinggian maksimum dari rata-rata tahunan ${ }^{[19]}$. Karena adanya tekanan pada permukaan air di lautan, maka ini akan menimbulkan tinggi gelombang dan arus permukaan terbentuk. Apabila tinggi gelombang besar maka kecepatan arus berubah membesar sehingga terbentuk arus sejajar pantai yang besar ${ }^{[16]}$ yang dapat menimbulkan abrasi di pantai ${ }^{[20]}$. Oleh karena itu pengukuran tinggi gelombang laut beserta dan energi gelombang laut pada angin musim timur dan musim peralihan sangat penting untuk dilakukan dalam memahami variabilitas musiman tinggi gelombang laut berserta energinya melalui pengukuran lapangan di daerah Serangai, Kecamatan Batik Nau, Bengkulu Utara.

\section{KESIMPULAN}

Berdasarkan hasil penelitian arus laut yang telah dilaksanakan di daerah Serangai Kecamatan Batik Nau, Bengkulu Utara yang dilakukan pada tanggal 5-7 November 2018 maka dapat disimpulkan bahwa tinggi gelombang laut di daerah pantai berkisar 0,8 hingga 1,6 $\mathrm{m}$ dengan hasil tinggi gelombang significant $(\mathrm{Hs})$ sebesar $1,38 \mathrm{~m}$. Tinggi gelombang minimum (Hmin) yang teramati sebesar $0.8 \mathrm{~m}$ pada tanggal 5 November 2018 pada pukul 11:16 WIB, sedangkan tinggi gelombang maksimum (Hmax) sebesar 1,6 m pada tanggal 7 November 2018 pukul 05:15 WIB. Berdasarkan perhitungan energi gelombang yang telah dilakukan diperoleh bahwa energi gelombang laut pada daerah pantai berkisar 600-1800 $\mathrm{J} / \mathrm{m}^{2}$. Berdasarkan hasil yang diperoleh dapat juga disimpulkan bahwa tinggi gelombang dan energi gelombang laut yang besar merupakan salah satu faktor penyebab abrasi di daerah Serangai, Kecamatan Batik Nau. Bengkulu Utara. Hal ini dikarenakan tinggi gelombang laut dapat memicu keberadaan arus sejajar pantai yang mempercepat proses abrasi pantai. Namun demikian masih diperlukan penelitian lanjutan untuk mengamati tinggi gelombang dan energi laut pada musim yang berbeda untuk mengkaji potensi energi gelombang laut secara komprehensif di daerah Serangai Bengkulu Utara yang bangkali dapat dipergunakan untuk kebutuhan akan energi arternatif di daerah Bengkulu bagian Utara.

\section{UCAPAN TERIMAKASIH}

Penulis mengucapkan banyak terima kasih kepada Pusat Penelitian Oseanografi (P2O) Lembaga Ilmu Pengetahuan Indonesia (LIPI) yang telah mengijinkan penggunaan alat $S B E$ 26 Plus Seagauge Wave untuk survey tinggi dan periode gelombang di Desa Serangai, Bengkulu Utara. Penelitian ini didanai oleh program Demand Driven Research Grant (DDRG) tahun 2018 melalui kegiatan Coral Reef Rehabilitation and Management ProgramCoral Triangle Initiative (COREMAP-CTI), LIPI. Ucapan terimakasih kepada kru kapal laut dan kepada mahasiswa Jurusan Fisika yang telah banyak membantu dalam pengambilan data di lapangan. 


\section{DAFTAR PUSTAKA}

1 Lubis, A.M., Hanapi, R., Sinaga, J., Samdara, R., dan Harlianto, B. 2021. Investigasi Perubahan Garis Pantai di Daerah Abrasi Pantai Bengkulu Utara dengan Menggunakan Teknologi Unmanned Aerial Vehicle (UAV), under review, Majalah Globe.

2 Samdara, R. 2014. Laju Perubahan Muka Air Laut Di Wilayah Perairan Pantai Bengkulu Dengan Menggunakan Satelit Altimetry. Jurnal Fisika FLUX, 11 (2), 197-203.

3 Church J, dan White, N. 2006. A $20^{\text {th }}$ Century acceleration in global sea-level rise, Geophysical Research Letters, 33 (1), L01602.

4 Church J, dan White, N. 2011. Sea-level rise from the late $19^{\text {th }}$ to the early $21^{\text {st }}$ Century. Surveys in Geophysics, 32, 585-602.

5 Williams, S.J. 2013. Sea level rise implications for coastal regions. Journal of Coastal Research, 63, 10063, 184-196.

6 Wahyudi, Solihin dan Ferry, S. 2005. Pengaruh Spektrum Gelombang Terhadap StabilitasBatu Pecah pada Permukaan Cellular CofferdamAkibat Gelombang Overtopping. Jurnal Teknologi Kelautan, 9 (1), 9-17.

7 Cruz, J. 2008. Ocean wave energy: current status and future perspectives. Heidelberg: Springer, hal. 220-241.

8 Holthuijsen, L.H. 2007. Waves in Oceanic and Coastal Waters. Cambridge University Press, hal. 1- 404. ISBN 0521860288.

9 Jejen, H., Jenhar, Yusuf, M., dan Indrayat, M. 2103. Dinamika Penjalaran Gelombang Menggunakan Model CMS-Wave Di Pulau Parang Kepulauan karimun Jawa. Jurnal Oseanografi, 2 (3), 255-264.

10 Mizan, A.Z., Indra, P.B., Denny, S.N., Agus, S.A., Heriyosi, S., dan Petrus, S. 2019. Analisis Spektrum Gelombang Di Perairan Pulau Panjang. Indonesia Journal of Oceanography, 1 (1), 1-10.

11 Rahma, T.D., Rifai, A., dan Atmodjo, W. 2015. Dinamika Transformasi Gelombang Menggunakan Model CMS-Wave di Pantai Boom Tuban, Jawa Timur. Jurnal Oseanografi, 4 (1), 195-205.

12 Intan, M.R., Denny, S.N., dan Indrayati, E. 2012. Kajian Arus Sejajar Pantai (Longshore Current) Akibat Pengaruh Transformasi Gelombang di Perairan Semarang. Jurnal of Oceanografi, 1(2), 128-138.

13 Utami, S. 2012. Study Potensi Pembangkit Listrik Tenaga Gelombang Laut Dengan Menggunakan Sistem Ocilating Water Column (OWC) Di Tiga Puluh Wilayah Kelautan Indonesia. Universitas Indonesia. Depertemen Teknik Elektro.

14 Ryan, D.Y., Nugroho, D., dan Setiyono, H. 2015. AnalisiS Karakteristik Gelombang di Perairan Kabupaten Batu Bara, Sumatra Utara. Jurnal Oceanografi, 4 (2), 400-407.

15 Shintawati, W. D. 2019. Study Pembangkit Listrik Tenaga Gelombang Laut Sistem Ocilating Water Coumn (OWC) di Kelautan Indonesia. Skripsi, Program Studi Elektro, Universitas Muhamadiyah Surakarta.

16 Lubis, A.M., Veronica N., Saputra R., Sinaga J., Hasanuddin, M., dan Kusmanto, E. 2020. Investigasi Arus Sejajar Pantai (Longshore Current) di Daerah Abrasi Bengkulu Utara. Jurnal Kelautan Tropis, 23 (3), 316-324.

17 Dronkers, J. 2005. Dynamics of Coastal Systems, World Scientific, Singapore.

18 Ahdannabiel, H., Widada, S., dan Hariadi. 2017. Distribusi Sedimen Dasar Akibat Arus Sejajar Pantai di Sekitar Groin di Perairan Pantai Widuri Pemalang. Jurnal Oseanografi, 6 (4), 650-658. 
19 Labania, H.M.D., Sunarto dan Khakhim, N. 2018. Variabilitas Musiman Gelombang dan Arus Laut di Perairan Pantai Lembasada, Kabupaten Donggala. Gravitasi, 17 (10), 1-10. 20 Horikawa, K. 1988. Nearshore Dynamics and Coastal Process. Theory, Measurement and Predictive Model, University of Tokyo Press. 